\title{
THE WHITE-THROATED SPARROW THAT STAYED
}

\section{VELMA SPIZAWKA, Box 47, Spalding, Saskatchewan. SOK 4CO}

For generations, the comings and goings of migrating birds have mystified man, giving rise to many theories and speculations. There was the "transformation" or "transmutation" theory which even scholars such as Pliny and Aristotle believed to be true; it was the idea that a given bird could change into another form or species. ${ }^{2,3}$ There was another theory which even the great ornithologist Carolus Linnaeus could not be talked out of, which was about "immersion." Part of this theory explained that some birds roll up into a ball and drop into the water; it was considered true because "fisherman sometimes caught these lumps in their fishing nets." Still another explanation, a bit of folklore, states that "sparrows were being generated spontaneously from mud and horsehair." On our side of the continent, the Innuit and Indians believed that some small birds hitched rides on the backs of larger birds, such as geese and herons.

We have come a long way in our understanding about some of the mysteries of migrations, but nonetheless, the unusual and the unexpected happenings still raise questions and add some excitement to our winter bird watching. Once in a while, a single bird, for some reason or another, remains behind in the fall instead of flying to warmer regions with the rest of the flock. One such bird, a White-throated Sparrow, missed the boat going south last fall and fed in our backyard all winter.
How does a bird that usually goes south manage to survive a central Saskatchewan prairie winter? We see the year-round resident House Sparrows sheltering in available Purple Martin houses and all sorts of nooks and crannies as well as in the dense branches of evergreens; so we hoped that the white-throat also found some such sheltered niche for itself.

The white-throat seems to be a "loner," even in a flock of other birds. It is the same size as a House Sparrow, but the head stripes and lightcoloured throat patch set it apart. Its tail too is different from other sparrows. The tail is slightly longer and more slender, usually held at a more acute angle. On rare occasions, it flicks its tail feathers, much as juncos do.

House Sparrows get spoofed off the feeders at the least provocation. The native birds - the grosbeaks, redpolls and siskins - take advantage of this behaviour and make good use of the unoccupied feeder. The whitethroat was no exception; often it was the only bird left at the feeder. In the very cold weather in the middle of winter, we would see this little sparrow all huddled up, looking like a little ball of fur in its fluffed up feathers.

The Audubon Society Master Guide to Birding shows the Whitethroated Sparrow's usual winter range as being "casually in southern Canada." ${ }^{6}$ The Birds of Canada 


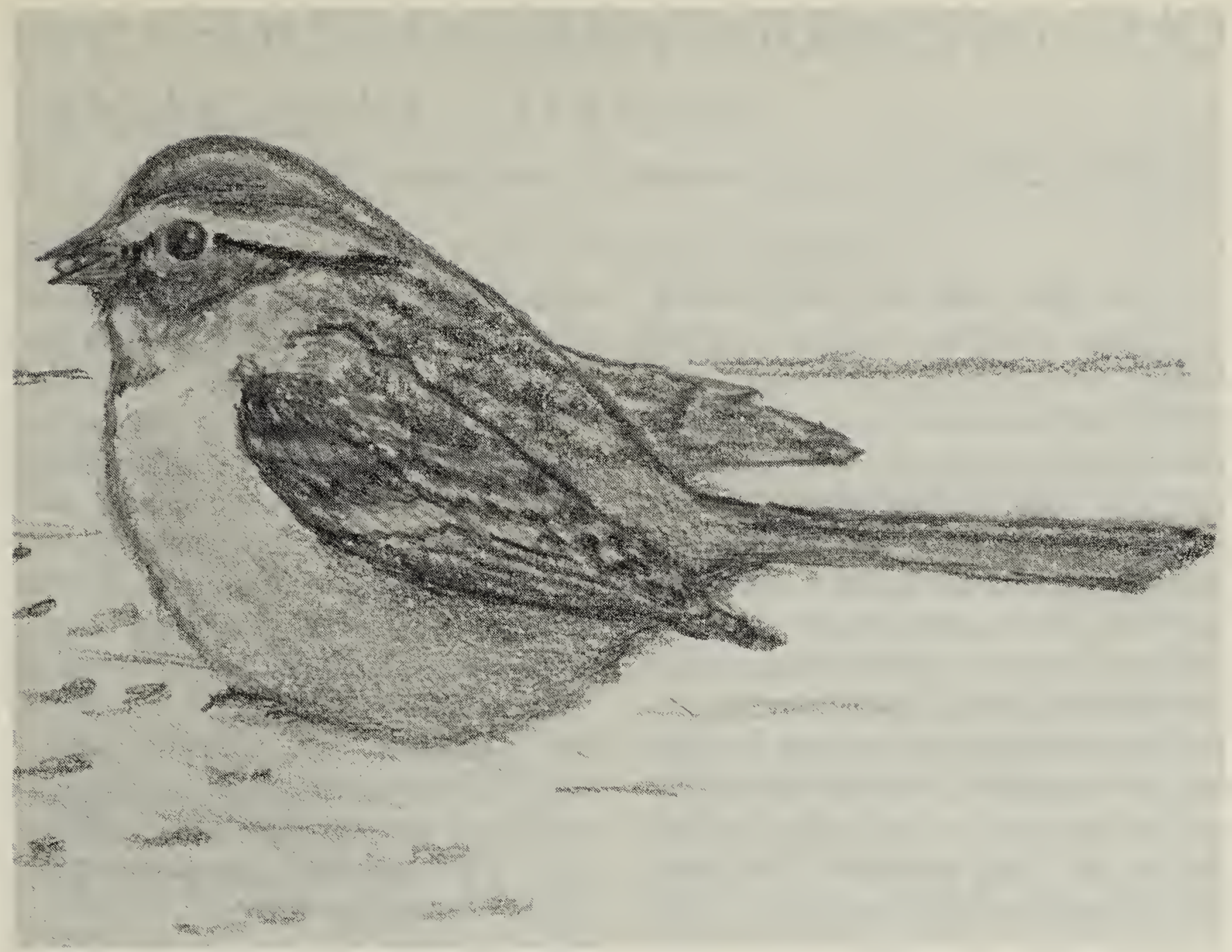

shows this bird as wintering only in eastern Canada and in southern British Columbia, and "very rarely elsewhere." 4

The annual Christmas Bird Count (CBC) shows small numbers of Whitethroated Sparrows for the prairies, the farthest northerly record in Saskatchewan in recent years as being in Porcupine Plain in $1991 .^{5}$ The Alberta CBC seems to average about two white-throats per year. ${ }^{1}$

The unusually early onset of winter, starting with the two snowstorms in October, may have been a deciding factor in this bird's decision to remain in the area. Finding a ready source of food at the feeders may also have been a contributing factor. Welty and Baptista in The Life of Birds state that birds are "creatures of comfortable habitat and will change their habits only under necessity." 8
1. Alberta Naturalist. Vol. 15, No. 4, Winter 1985.

2. BAKER, R. 1980. The mystery of migration.

3. DORST, J. 1961. The migration of birds. American edition. HoughtonMifflin, Boston. 476 pp.

4. GODFREY, W.E. 1986. The birds of Canada. Nat. Mus. of Canada, Ottawa. 595 pp.

5. HARRIS, W.C. 1991. 49th Annual Saskatchewan Christmas Bird Count - 1990. Blue Jay 49:7-26.

6. PETERSON, W. R. 1983. White-throated Sparrow. In Farrand, John, Jr. Audubon Society master guide to birding. Vol. 3. Knopf, New York. 399 pp.

7. WEIDENSAUL, S. 1991. The birders miscellany. Simon and Schuster, New York. 100 pp.

8. WELTY, J.C. and BAPTISTA, L.F. 1988. The life of birds. W.B. Saunders. 495 pp. 